\title{
PEMANFAATAN ASET DESA DALAM UPAYA MENINGKATKAN PENDAPATAN DESA
}

\section{Linda Oksafiama, Suparnyo dan Anggit Wicaksono}

\author{
Email : lindaoksa10@gmail.com, suparnyo@umk.ac.id, anggit.wicaksono@umk.ac.id \\ Fakultas Hukum Universitas Muria Kudus
}

\begin{abstract}
ABSTRAK
Penelitian yang berjudul "Pemanfaatan Aset Desa dalam Upaya Meningkatkan Pendapatan Desa" ini secara umum bertujuan untuk membandingkan pemanfaatan aset desa di dua desa yakni Desa Getas Pejaten dan Ngembal Kulon. Dikarenakan dari kedua Desa ini ada yang mengalami keuntungan maupun kerugian. Penelitian ini juga untuk mengetahui mekanisme pemanfaatan aset desa yang dilakukan oleh desa sesuai dengan ketentuan yang berlaku, serta untuk mengetahui akibat hukum yang dapat timbul jika pemanfaatan aset desa tidak dilakukan sesuai ketentuan yang berlaku. Metode penelitian yang digunakan yaitu yuridis sosiologis. Pengumpulan data penulis menggunakan data primer dan data sekunder. Dari hasil penelitian dapat diketahui bahwa pemanfaatan aset Desa ada yang mengalami keuntungan dan juga kerugian. Desa yang mengalami kerugian karena tidak mengikuti mekanisme yang telah diterapkan pemerintah dalam PP No. 43 Tahun 2014 Pasal 110 ayat (2) yang menyatakan bahwa Pengelolaan kekayaan milik desa harus diatur dalam Peraturan Desa yang berpedoman kepada Peraturan Menteri. Lebih lanjut, Peraturan Menteri Dalam Negeri Nomor 1 Tahun 2016 tentang Pengelolaan Aset Desa dalam Pasal 11 ayat (2) menyatakan bahwa pemanfaatan aset desa terbagi dalam empat bentuk, yaitu sewa, pinjam pakai, kerjasama pemanfaatan, bangun guna serah atau bangun serah guna. Selanjutnya Pasal (3) menyatakan bahwa Pemanfaatan aset desa harus ditetapkan dalam Peraturan Desa. Maka jika pemerintah Desa ingin memanfaatkan aset desa yang dimiliki, harus memiliki Peraturan Desa. Pemerintah Desa Getas Pejaten memanfaatkan aset desanya yakni tanah kas desa untuk dijadikan lokasi gedung DPRD yang menyewakan kepada pemerintah kabupaten Kudus. Lain halnya dengan pemerintah desa Ngembal kulon yang menyewakan 20 tahun tanah kasnya dijadikan pasar modern oleh PT. Panca Surya. Tindakan hukum pemerintah desa yang bekerjasama dengan pihak lain dalam memanfaatkan aset desanya, maka pemerintah bertindak sebagai pihak swasta dan tunduk kepada hukum privat. Maka pemerintah desa jika membuat perjanjian haruslah tunduk pada Pasal 1320 KUH Perdata sebagai syarat sahnya perjanjian yaitu kesepakatan, kecakapan, hal tertentu dan kausa yang halal.
\end{abstract}

Kata Kunci : Pemanfatan, Aset Desa, Pendapatan Desa 


\section{PENDAHULUAN}

Aset desa merupakan salah satu kekayaan desa yang dapat dikelola oleh pemerintah desa agar tercapainya kesejahteraan warga desa sesuai dengan harapan pemerintah yang tertuang dalam alinea ke-4 Pembukaan Undang-Undang Dasar Negara Republik Indonesia Tahun 1945 (UUD NRI 1945) yang berbunyi :

"Kemudian daripada itu, untuk membentuk suatu Pemerintahan Negara Indonesia yang melindungi segenap bangsa Indonesia dan seluruh tumpah darah Indonesia dan untuk memajukan kesejahteraan umum, mencerdaskan kehidupan bangsa, dan ikut melaksanakan ketertiban dunia yang berdasarkan kemerdekaan, perdamaian abadi dan keadilan sosial".

Dalam mewujudkan tujuan Negara tersebut pemerintahan diselenggarakan oleh pemerintah pusat hingga pemerintah desa sebagaimana dapat disimpulkan dari ketentuan Pasal 18 B UUD NRI 1945 :
(1) Negara mengakui dan menghormati satuan-satuan pemerintah daerah yang bersifat khusus atau bersifat istimewa yang diatur dengan undang-undang.

(2) Negara mengakui dan menghormati kesatuan-kesatuan masyarakat hukum adat beserta hak-hak tradisionalnya sepanjang masih hidup dan sesuai dengan perkembangan masyarakat dan prinsip Negara Kesatuan Republik Indonesia, yang diatur dalam undang-undang.
Diantara bentuk kesatuan masyarakat hukum dalam Pasal 18B UUDNRI 1945 tersebut adalah Desa. Desa atau yang disebut dengan nama lain menurut Pasal 1 angka 1 UndangUndang Nomor 6 Tahun 2014 tentang Desa (selanjutnya ditulis UU Desa) adalah kesatuan masyarakat hukum yang memiliki batas wilayah yang berwenang untuk mengatur dan mengurus urusan pemerintahan, kepentingan masyarakat setempat berdasarkan prakarsa masyarakat, hak asal usul, dan/atau hak tradisional yang diakui dan dihormati dalam sistem pemerintahan Negara Kesatuan Republik Indonesia.

Peraturan Pemerintah Nomor 47

Tahun 2015 Pasal 113 menerangkan bahwa pengelolaan aset desa diatur dengan peraturan menteri yang menyelenggarakan urusan pemerintahan di bidang pemerintahan dalam negeri.

Sebagai pedoman pelaksanaan Pengelolaan aset Desa pemerintah menerbitkan Peraturan Menteri Dalam Negeri Republik Indonesia Nomor 1 Tahun 2016 Pasal 7 menyebutkan bahwa pengelolaan aset Desa meliputi :

a. perencanaan;

b. pengadaan;

c. penggunaan;

d. pemanfaatan;

e. pengamanan;

f. pemeliharaan;

g. penghapusan;

h. pemindahtanganan;

i. penatausahaan;

j. pelaporan;

k. penilaian;

1. pembinaan;

m. pengawasan dan

n. pengendalian. 
Salah satu pengelolaan aset desa yang disebutkan dalam Peraturan Menteri Dalam Negeri Nomor 1 Tahun 2016 Pasal 11 yaitu dalam bentuk pemanfaatan. Pemanfaatan aset desa itu meliputi, (1) sewa (2) pinjam pakai (3) kerjasama pemanfaatan (4) bangun guna serah atau bangun serah guna. Mengenai mekanime pemanfatan aset desa diatur dalam Pasal 5 ayat (2) Peraturan Daerah Kabupaten Kudus Nomor 17 Tahun 2006 tentang Keuangan Desa dalam Pasal 5 yaitu Penyerahan pengeloaan bondo desa dilaksanakan melalui mekanisme lelang atau penawaran terbuka oleh panitia yang dibentuk dengan Keputusan Kepala Desa yang disampaikan kepada BPD dengan tembusan Camat. Peraturan Daerah Nomor 9 Tahun 2008 Perubahan Atas Peraturan Daerah Kabupaten Kudus Nomor 17 Tahun 2006 Tentang Keuangan Desa dalam pasal 4a ayat (1) menerangkan bahwa untuk kekayaan desa yang pengelolaanya oleh pihak lain harus mendapat persetujuan BPD. Pasal 4a ayat (3) menerangkan lebih lanjut bahwa pemanfaatan aset desa diatur dalam Peraturan Desa yang berpedoman pada Peraturan Bupati.

Berdasarkan uraian mengenai pemanfaatan aset desa diatas, ternyata dalam memanfatkan aset desa ada yang mengalami keuntungan adapula yang mengalami kerugian. Hal ini dikuatkan dengan informasi yang peneliti peroleh dari hasil wawancara dengan kepala Desa Ngembal Kulon $\mathrm{Hj}$. Arimi bahwa di Ngembal Kulon banyak memiliki aset Desa, Namun ada salah satu aset Desa yang saat ini sangat merugikan Desa Ngembal Kulon yaitu tanah kas Desa Ngembal Kulon yang disewakan dalam waktu 20 tahun kepada PT.
Panca Surya untuk dijadikan pasar modern. Namun dalam kenyataanya pihak penyewa tidak dapat membayar sewa selama 3 tahun terakhir.

Lain halnya dengan Desa Getas Pejaten yang menyewakan bengkoknya untuk dijadikan lokasi gedung DPRD Kudus mengalami hasil yang baik atau dengan kata lain memberikan keuntungan bagi pemerintah desa Getas Pejaten.

Atas dasar bentuk pemanfaatan aset Desa yang kenyataannya menunjukkan ada Desa yang mengalami kerugian dan ada juga yang mengalalmi keuntungan itulah peneliti tertarik untuk mengkaji hal tersebut terutama tentang pengelolaan aset Desa yang pemanfaatannya dikelola oleh pihak lain yang dirumuskan dalam suatu permasalahan sebagai berikut :

1. Apakah mekanisme pemanfaatan aset desa telah dilakukan sesuai ketentuan yang berlaku?

2. Apa akibat hukum jika pemanfaatan aset desa tersebut tidak sesuai dengan mekanisme yang ada?

\section{METODE PENELITIAN}

Metode Penelitian yang digunakan dalam penelitian ini yaitu metode pendekatan yuridis sosiologis, dengan menggunakan data primer melalui wawancara. Adapun spesifikasi penelitian yang digunakan yaitu deskriptif analitis. Penentuan sampelnya menggunakan cara nonrandom purposive sampling atau penarikan sampel dilakukan dengan cara mengambil subyek yang didasarkan pada tujuan tertentu. 
HASIL PENELITIAN DAN

PEMBAHASAN

\section{A. Mekanisme Pemanfaatan Aset Desa}

1. Mekanisme Menurut Peraturan Perundang-Undangan

Aset desa merupakan barang milik desa yang berasal dari kekayaan asli desa, dibeli atau diperoleh atas beban anggaran pendapatan dan belanja desa atau perolehan hak lainnya yang sah. Salah satu asset desa yang dapat dikelola adalah tanah kas desa. Tanah kas desa merupakan tanah milik desa yang pengelolaannya dapat dimanfaatkan oleh pemerintah desa sendiri maupun pemanfaatannya oleh pihak lain, namun dengan catatan tanah tersebut masih hak milik desa. Tanah kas desa menjadi sumber pendapatan desa yang pengelolaan dan penggunaannya untuk urusan pemerintahan desa. Pengelolaan tanah kas desa haruslah berdasarkan dari musyawarah desa atau biasa disebut rembug desa. Dalam musyawarah ini keterlibatan masyarakat sangatlah penting yaitu mulai dari unsur BPD, LKMD, RT, dan RW serta tokoh masyarakat yang ada di dalam desa tersebut.

Pemegang kekuasaan aset desa merupakan kepala desa yang menguasakan sebagian kekuasaannya kepada perangkat desa. Dalam hal memanfaatkan aset desa ini haruslah didasarkan pada asas kepentingan umum, fungsional, kepastian hukum, keterbukaan, efisiensi, efektivitas, akuntabilitas, dan kepastian nilai ekonomi. Kepala desa dalam memanfaatkan aset desa dilarang merugikan kepentingan umum, membuat keputuan yang menguntungkan diri sendiri, anggota keluarga, pihak lain dan/atau golongan tertentu.

Pasal 11 ayat (1) sampai (3) Peraturan Menteri Dalam Negeri Republik Indonesia Nomor 1 Tahun 2016 tentang Pengelolaan Aset Desa menyebutkan bahwa :

a. Pemanfaatan asset desa dapat dilaksanakan sepanjang tidak dipergunakan langsung untuk menunjang penyelenggaraan pemerintahan desa.

b. Adapun bentuk pemanfaatan aset desa dapat berupa sewa, pijam pakai, kerjasama pemanfaatan dan bangun guna serah atau bangun serah guna.

c. Selanjutnya pemanfaatan aset desa tersebut haruslah diatur di dalam Peraturan Desa. Mengenai pemanfaatan aset desa berupa sewa diperjelas dalam Pasal 12, yang menyatakan sebagai berikut :

1) Pemanfaatan aset desa berupa sewa tidak diperbolehkan merubah status kepemilikan desa.

2) Jangka waktu penyewaan paling lama 3 (tiga) tahun dan dapat diperpanjang.

3) Penyewaan aset desa haruslah didasarkan pada perjanjian yang memuat poin berikut ini :

(a) Para pihak yang terlibat dalam perjanjian.

(b) Objek perjanjian sewa menyewa.

(c) Jenis, luas atu jumlah barang, besaran sewa dan jangka waktu sewa.

(d) Tanggung jawab penyewa atas biaya operasional dam pemeliharaan jangka waktu sewa.

(e) Hak dan kewajiban oara pihak yang terkait dalam perjanjian. 
(f) Keadaan diluar kemampuan para pihak (force majeure) dan

(g) Persyaratan lain yang dianggap perlu.

Selanjutnya untuk pemanfaatan aset desa yang terakhir yaitu bangun guna serah atau bangun serah guna hal ini diatur dalam Pasal 15 dan 16 yaitu sebagai berikut :

Bangun guna serah atau bangun serah guna ini dilakukan dengan pertimbangan pemerintah desa yang memerlukan bangunan dan fasilitas bagi penyelenggaraan pemerintahan desa dan juga karena tidak tersedia dana dalam APBDesa untuk menyediakan bangunan dan fasilitas tersebut. Adapun kewajiban pihak lain yang bekerjasama dengan pemerintah desa yaitu membayar kontribusi ke rekening kas desa setiap tahun dan memelihara obyek bangun guna serah atau bangun serah guna. Besaran kontribusi ditetapkan berdasarkan hasil perhitungan tim yang dibentuk oleh pemerintah daerah kabupaten/kota. Obyek bangun guna serah dilarang dijaminkan, digadaikan, atau dipindahtangankan oleh pihak lain.

Pasal 16 Permendagri No. 1 Tahun 2016 menyebutkan bahwa jangka waktu bangun guna serah/bangun serah guna paling lama 20 tahun dan dapat diperpanjang. Perpanjangan waktu tersebut dapat dilakukan setelah terlebih dahulu dilakukan evaluasi oleh tim yang dibentuk oleh kepala desa yang difasilitasi oleh pemerintah kabupaten/kota. Jika jangka waktu bangun guna serah diperpanjang, maka pemanfaatan dilakukan melalui kerjasama pemanfaatan. Bangun guna serah atau bangun serah guna dilaksanakan berdasarkan surat perjanjian yang sekurang-kurangnya memuat :

a. Para pihak yang terikat dalam perjanjian.

b. Obyek bangun guna serah.

c. Jangka waktu bangun para pihak yang terikat dalam perjanjian.

d. Penyelesaian perselisihan.

e. Keadaan diluar kemampuan para pihak.

f. Persyaratan lain yang dianggap perlu.

g. Bangunan dan fasilitasnya yang menjadi bagian hasil dari pelaksanaan bangun guna serah atau bangun serah guna harus dilengkapi dengan izin mendirikan bangunan (IMB) atas nama pemerintah desa.

Peraturan Daerah Kabupaten Kudus Nomor 17 Tahun 2006 tentang Keuangan Desa dalam Pasal 4 menjelaskan sebagai berikut :

(1) Kekayaan desa meliputi :
a. Tanah kas desa
b. Pasar desa
c. Pasar hewan desa
d. Bangunan desa
e. Obyek rekreasi desa
f. Pemandian umum desa dan
g. Lain-lain kekayaaan milik desa

(2) Kekayaan desa sebagaimana dimaksud pada ayat (1), terbatas pada kekayaan desa yang menjadi kewenangan penyelenggaraan urusan rumah tangga desa.

(3) Pemerintah Desa dapat mengenakan pungutan terhadap pemakaian kekayaan desa sebagaimana dimaksud pada ayat (1) huruf b, huruf c, huruf d, huruf e, huruf f, dan huruf $g$.

(4) Penetapan besarnya pungutan terhadap pemakaian kekayaan desa sebagaimana dimaksud pada 
ayat (3) diatur di dalam Peraturan Desa.

(5) Pengelolaan kekayaan desa yang pemanfaatannya diserahkan kepada pihak lain lebh dari satu tahun harus mendapatkan persetujuan BPD.

(6) Aturan mengenai pengelolaan kekayaan desa diatur lebih lanjut dalam peraturan desa yang berpedoman pada peraturan bupati.

Peraturan Daerah Kabupaten

Kudus Nomor 9 Tahun 2008 tentang Perubahan atas Peraturan Daerah Kabupaten Kudus Nomor 17 Tahun 2006 tentang Keuangan Desa dalam Pasal 4a ayat (3) menyebutkan bahwa pengelolaan dan pemanfaatan kekayaan desa diatur lebih lanjut dalam peraturan desa yang berpedoman pada peraturan bupati. Namun dalam hal ini Peraturan Bupati Kabupaten Kudus Nomor 16 Tahun 2015 tentang Pedoman Pengelolaan Keuangan Desa dalam Pasal 13, menyatakan bahwa Pengelolaan Kekayaan Milik Desa diatur dalam Peraturan Bupati tersendiri.

Namun dalam wawancara dengan Bagian Hukum Kabupaten Kudus yaitu Bapak Rudy, beliau mengatakan bahwa untuk peraturan bupati tentang pengelolaan kekayaan milik desa belum diatur, karena masih konsep. ${ }^{63}$ Jadi, pada dasarnya mekanisme pemanfaatan aset desa seharusnya ada di peraturan masing-masing desa yang peraturan desa tersebut harus berpedoman pada Peraturan Daerah Kabupaten Kudus Nomor 5 Tahun 2008 tentang Pedoman Pembentukan

${ }^{63}$ Rudy, Wawancara Pribadi, Bagian Hukum Pemda Kabupaten Kudus, 7 Juli 2017. dan Mekanisme Penyusunan Peraturan Desa.

2. Mekanisme Pemanfaatan Aset Desa Menurut Desa Getas Pejaten dan Ngembal Kulon

Penulis melakukan wawancara pada dua desa yaitu Desa Getas Pejaten dan Ngembal Kulon antara lain dengan Sekretaris Desa Getas Pejaten dan Kepala Desa Ngembal Kulon.

Dari narasumber pertama penulis mendapatkan informasi bahwa tanah yang diperuntukkan untuk gedung DPRD kabupaten kudus merupakan tanah kas/aset Desa Getas Pejaten yang disewakan kepada Pemerintah Daerah Kabupaten Kudus dalam jangka waktu 3 tahun dan dapat di perpanjang.

Wawancara kedua dilakukan penulis kepada Desa Ngembal Kulon yaitu Ibu Arimi dengan menanyakan pertanyaan yang sama kepada Desa Ngembal Kulon sebagai narasumber kedua, bahwa pemanfaatan aset desa yang dilakukan oleh pemerintah Desa Ngembal Kulon dalam hal ini meyewakan tanah kas desa kepada PT. Panca Surya untuk dijadikan Pasar Modern mereka mengalami kerugian, dikarenakan pihak penyewa menunggak pembayaran selama tiga tahun kepada Pemerintah Desa Ngembal Kulon.

3. Analisis dan Kesimpulan

Dari wawancara penulis dengan kedua narasumber diatas ternyata pemanfaatan aset desa ada yang menguntungkan adapula yang tidak. Sebagai contoh desa Getas Pejaten yang mengalami peningkatan pendapatan dikarenakan biaya sewa tanah kas desa yang setiap tahun mengalami kenaikan. Lain halnya dengan desa Ngembal Kulon yang justru mengalami kerugian diakibatkan 
pembayaran sewa yang nunggak selama 3 tahun terakhir.

Adapun untuk mekanisme pemanfaatan aset Desa di masing masing Desa yaitu di Desa Getas Pejaten sudah melewati mekanisme dengan benar dan baik, hal ini dibuktikan dengan adanya perdes tentang pengelolaan kekayaan desa yang di dalamnya memuat mekanisme pemanfaatan aset desa. Desa ngembal kulon belum melakukan mekanisme menurut peratura perundang-undangan dikarenakan desa ngembal tidak mempunyai Peraturan Desa yang mengatur tentang pemanfaatan aset desa atau kekayaan desa seperti halnya di Desa Getas Pejaten.

Berikut ini mekanisme pemanfatan aset desa yang diatur di dalam Peraturan Perundang-Undangan yaitu :

1. Peraturan Pemerintah Republik Indonesia Nomor 43 Tahun 2014 Tentang Peraturan Pelaksanaan Undang-Undang Nomor 6 Tahun 2014 Tentang Desa dalam Pasal 110 ayat (1) menyebutkan, jika pengelolaan kekayaan milik Desa tujuannya yaitu untuk meningkatkan kesejahteraan masyarakat dan untuk meningkatkan pendapatan Desa. Dijelaskan lebih lanjut dalam Pasal (2) bahwasanyya pengelolaan kekayaan milik Desa harus diatur dalam Peraturan Desa yang berpedoman pada Peraturan Menteri.

2. Peraturan Menteri dalam Negeri Nomor 1 Tahun 2016 tentang Pengelolaan Aset Desa dalam Pasal 11 ayat (2) menyatakan bahwa bentuk pemanfaatan aset desa dapat berupa : a. Sewa

b. Pinjam pakai

c. Kerjasama pemanfaatan

d. Bangun guna serah atau bangun serah guna

Ayat (3) berbunyi :

Pemanfaatan aset desa yang dimaksud di dalam ayat (2) di tetapkan dalam peraturan desa

3. Peraturan Daerah Kabupaten Kudus Nomor 17 Tahun 2006 tentang Keuangan Desa dalam Pasal 4 ayat (5) menyatakan bahwa kekayaan desa yang pengelolaanya diserahkan kepada pihak lain lebih dari 1 tahun harus mendapat persetujuan BPD.

Ayat (6) berbunyi :

Penyerahan pengelolaan kekayaan desa, diatur lebih lanjut oleh perturan desa yang berpedoman pada peraturan bupati.

4. Peraturan Daerah Nomor 9 Tahun 2008 tentang Perubahan Atas Peraturan Daerah Kabupaten Kudus Nomor 17 Tahun 2006 tentang Keuangan Desa dalam Pasal 4a ayat (3) menegaskan lagi jika pengelolaan dan pemanfaatan kekayaan desa diatur lebih lanjut dalam peraturan desa yang berpedoman pada peraturan bupati, dalam hal ini Peraturan Bupati Nomor 5 Tahun 2008 tentang Pedoman Pembentukan dan Mekanisme Penyusunan Peraturan Desa.

5. Peraturan Bupati Kudus Nomor 16 Tahun 2015 tentang Pedoman Pengeloaan Keuangan Desa dalam Pasal 13 menyatakan bahwa pengelolaan kekayaan desa diatur 
dalam peraturan bupati tersendiri. Namun dalam wawancara penulis dengan bagian hukum di sekretariat kabupaten Kudus memang belum ada peraturan bupati yang dimaksud.

Dari mekanisme di atas, sangat terlihat jelas bahwasanya untuk memanfaatkan aset desa yang dimiliki, pemerintah desa harus mempunyai pedoman yaitu dalam hal ini Peraturan Desa yang mengatur tentang pemanfaatan aset Desa. Jika pemerintah Desa tidak memiliki Peraturan Desa yang dimaksud, maka pemerintah Desa tidak dapat melakukan pemanfaatan aset Desa yang dimiliki, apalagi membuat perjanjian sewa menyewa dengan pihak lain.

Dari kedua Desa yang penulis teliti ini, informasi yang dapat penulis himpun dari bagian humas di sekretariat DPRD kabupaten Kudus mengatakan bahwa $^{64}$ : Tanah yang ditempati untuk lokasi gedung DPRD Kudus merupakan Tanah Kas Desa Getas Pejaten, dengan perjanjian sewa menyewa dimana pihak Pemerintah Desa Kabupaten Kudus menyewa tanah kas Desa Getas Pejaten selama 3 tahun dengan sebuah perjanjian sewa menyewa yang berjudul SEWA MENYEWA SEBAGIAN TANAH KAS DESA GETAS PEJATEN SELUAS $\pm 8.670 \mathrm{M}^{2}$ YANG TERLETAK DI PERSIL 54 UNTUK LOKASI GEDUNG DPRD KABUPATEN KUDUS yang bernomor : 031/405 yang dalam hal ini yang bertanda tangan yaitu Indarto selaku Kepala Desa Getas Pejaten

64 Mira, Wawancara Pribadi, Humas Sekretariat DPRD Kudus, Oktober 2016. sebagai pihak pertama dan Drs. Adi Sadhono Murwanto, MM sebagai pihak kedua yaitu Plt. Sekretaris DPRD kabupaten Kudus. Dalam perjanjian sewa menyewa tersebut, di dalam Pasal 2 perjanjian sewa menyewa ini pihak kedua menyewa tanah kas desa Getas Pejaten mulai tanggal 1 januari 2017 sampai dengan 31 Desember 2019 dan dapat diperpanjang dengan kesepakatan kedua belah pihak.

Mekanisme sewa yang tertuang dalam perjanjian sewa-menyewa antara pemerintah desa Getas Pejaten dan Pemerintah Kabupaten Kudus Pasal 27 ayat (1) menyebutkan bahwa pemanfaatan aset Desa dilakukan berdasarkan :

a. Menguntungkan Desa, menguntungkan disini sudah tercermin dalam perjanjian sewa menyewa antara pemerintah Desa Getas Pejaten dan pemerintah Kabupaten Kudus dengan naiknya sewa pertahun.

b. Jangka waktu paling lama 3 (tiga) tahun dan dapat diperpanjang, sewa menyewa antara pemerintah Desa Getas Pejaten dan Pemerintah Kabupaten Kudus berjangka waktu 3 tahun dan dapat diperpanjang.

c. Penetapan tarif sewa ditetapkan dengan keputusan kepala desa setelah mendapat persetujuan BPD, hal ini dibuktikan dengan adanya keputusan Kepala Desa Getas pejaten Nomor 141/15/2017 yang tertanggal 7 april 2017 tentang sewa menyewa sebagian Tanah Kas Desa Getas Pejaten untuk gedung DPRD Kabupaten Kudus.

Selanjutnya, persetujuan BPD dibuktikan dengan Keputusan 
Badan Permusyawaratan Desa Getas Pejaten Nomor 141/3/2017 Tanggal 7 april 2017 tentang Persetujuan Rancangan

Keputusan Kepala Desa Getas Pejaten tentang sewa menyewa sebagian tanah kas Desa Getas Pejaten untuk gedung DPRD Kabupeaten Kudus.

Pada ayat (2) Pasal 27 menjelaskan jika pemanfaatan aset desa berupa sewa maka harus memenuhi sekurang-kurangnya memuat :

a. Pihak-pihak yang terikat dalam perjanjian.

Pihak pertama Pemerintah Desa Getas Pejaten.

Pihak kedua Pemerintah Kebupaten Kudus.

b. Obyek perjanjian sewa menyewa.

Obyek dalam perjanjian sewa menyewa nomor 031/405 adalah

Tanas Kas Desa Getas Pejaten yang terletak di Persil 54 Klas I seluas $\pm 8.670 \mathrm{~m}^{2}$ dengan batasbatas sebagai berikut :

Sebelah utara : jalan PUK

Sebelah selatan : PT. Pusaka

Raya

Sebelah Barat : Tanah PJKA

Sebelah Timur : Tanah Bondo Desa

c. Jangka waktu

Jangka waktu sewa menyewa tertuang dalam Pasal 2 perjanjian sewa menyewa nomor 031/405 jangka waktunya yaitu selam 3 tahun terhitung mulai tanggal 1 januari 2017 sampai dengan 31 desember 2019 dan dapat diperpanjang dengan kesepakatan para pihak.

d. Hak dan kewajiban para pihak

Tertuang dalam Pasal 5 dan 6 perjanjian sewa menyewa ini
Yaitu hak pihak pertama :

1. Menerima uang sewa dari pihak kedua

2. Memberikan teguran dan peringatan baik langsung maupun tidak langsung kepada pihak kedua atas kelalaian kewajiban pihak kedua

3. Memutuskan perjanjian apabila dikemudian hari ternyata perjanjian tidak digunakan sebagaimana yang disepakati para pihak.

Hak pihak kedua :

1. Menggunakan obyek perjanjian sesuai dengan jangka waktu perjanjian.

2. Menggunakan obyek perjanjian tanpa gangguan dari pihak lainnya selama jangka waktu perjanjian.

Kewajiban pihak pertama :

1. Menyerahkan obyek perjanjian kepada pihak kedua untuk dipergunakan oleh pihak kedua selama jangka waktu perjanjian.

2. Menjamin pihak kedua bahwa pihak pertama adalah pemilik atau yang menguasai obyek perjanjian dan membebaskan pihak kedua dari segala tuntutan yang timbul karena pengakuan kepemilikan dari pihak lainnya.

3. Tidak mengalihkan hak/menjual obyek perjanjian kepada pihak lain selain obyek perjanjian digunakan untuk lokasi gedung DPRD kabupaten Kudus.

Kewajiban pihak kedua : 
1. Membayar biaya sewa kepada pihak pertama sebagaimana dimaksud pada Pasal 3 ayat (1).

2. Mengembalikan obyek perjanjian kepada pihak pertama apabila jangka waktu perjanjian telah berakhir dan tidak diperpanjang oleh pihak kedua.

3. Memelihara, merawat, menjaga kebersihan, dan keindahan bangunan dan sarananya serta keamanan lingkungan.

e. Penyelesaian Perselisihan

Apabila terjadi perselisihan mengenai perjanjian ini akan diselesaikan oleh para pihak secara musyawarah mufakat dan jika dalam musyawarah mufakat tidak tercapai maka akan diselesaikan di kantor kepaniteraan pengadilan negeri kudus di Kudus.

f. Keadaan di Luar Kemampuan Para Pihak

Mengenai poin ini, di dalam perjanjian antara Desa Getas Pejaten dan Pemerintah Kabupaten Kudus tidak dijelaskan jika suatu saat terjadi keadaan-keadaan yang diluar kemampuan para pihak dalam perjanjian.

g. Peninjauan pelaksanaan perjanjian

Perjanjian sewa menyewa antara pemerintah Desa Getas Pejaten dan pemerintah kabupaten Kudus telah sesuai dengan apa yang ada di peraturan desa Getas Pejaten.

Selanjutnya, sampel kedua yaitu Desa Ngembal Kulon memanfaatkan aset desa yang berupa tanah kas desa yang disewakan kepada PT. Panca Surya selama 20 Tahun sejak tahun 2011 itu, merupakan pola perjanjian kerjsama yang berupa bangun guna serah. Hal ini dapat terlihat dari cara memanfaatkannya yaitu pihak lain yang memanfaatkan barang milik desa dengan mendirikan bangunan /sarana berikut fasilitasnya kemudian di dayagunakan oleh pihak lain tersebut dalam jangka waktu tertentu yang telah disepakati (20 tahun) kemudian selanjutnya diserahkan kembali tanah beserta bangunannya kepada pemrintah Desa setelah jangka waktu pemanfaatan berakhir. ${ }^{65}$

Desa Ngembal Kulon dalam penelitian yang peneliti teliti Desa Ngembal Kulon mengalami kerugian karena aset desa berupa tanah kas desa yang mereka miliki yang disewa oleh pihak lain sejak tahun 2011 itu tidak menguntungkan pihak Desa karena tanah yang disewa untuk lokasi pasar modern itu, kios kiosnya kurang diminati. Atas dasar kurang diminati itulah, pihak penyewa tidak dapat membayar sewa selama 3 tahun.

\section{B. Akibat Hukum Jika Pemanfaatan Aset Desa Tidak Sesuai Dengan Mekanisme Yang Ada}

Pemerintah atau Administrasi Negara adalah subyek hukum atau pendukung hak-hak dan kewajibankewajiban. Sebagai subyek hukum, pemerintah melakukan berbagai tindakan, baik tindakan nyata maupun tindakan hukum. Tindakan hukum merupakan tindakan yang dimaksudkan untuk menciptakan hak dan kewajiban.

65 Arimi, Wawancara Pribadi, Kepala Desa Ngembal Kulon, Juli 2017. 
Akibat hukum yang lahir dari tindakan hukum adalah akibat-akibat yang memiliki relevansi dengan hukum. Dengan kata lain, akibat-akibat hukum itu dapat berupa hal-hal sebagai berikut

(a) Jika menimbulkan beberapa perubahan hak, kewajiban, atau kewenangan yang ada.

(b) Jika menimbulkan perubahan kedudukan hukum bagi seseorang atau obyek yang ada.

(c) Jika terdapat hak-hak, kewajiban, kewenangan, atau status tertentu yang ditetapkan.

Setiap tindakan hukum pemerintah harus didasarkan pada peraturan perundang-undangan yang berlaku, maka dengan kata lain tindakan hukum pemerintah tidak diperbolehkan menyimpang atau bertentangan dengan peraturan yang bersangkutan, yang dapat menyebabkan akibat-akibat hokum yang muncul itu batal (nietig) atau dapat dibatalkan (nietigbaar). ${ }^{66}$

Kedudukan hukum pemerintah atau Administrasi Negara diatur dengan dua hukum yang berbeda yaitu hukum publik dan hukum privat dan akan menimbulkan akibat hukum yang berbeda beda pula. Jika pemerintah bertindak dalam kualitasnya sebagai pemerintah, maka hanya hukum publiklah yang berlaku, namun jika pemerintah bertindak tidak dalam kualitas pemerintah maka hukum privatlah yang berlaku. Maka dari itu jika pemerintah berkedudukan dalam hukum privat maka ia tidak berbeda dengan pihak swasta yaitu tunduk pada hukum privat.

${ }^{66}$ Ridwan, HR, Hukum Administrasi Negara, UII Press Yogyakarta, Yogyakarta, 2003, hal 83.
Pada tindakan hukum pemerintah di Desa ini, maka karena pemerintah desa bekerjasama dengan pihak lain dalam memanfaatkan aset desanya, maka pemerintah desa disini tunduk pada hukum privat. Maka apabila tindakan hukum pemerintah ini bertentangan dengan undang-undang yang berlaku maka dapat batal demi hukum.

Peraturan Pelaksana UndangUndang Nomor 6 Tahun 2014 yairu Peraturan Pemerintah Republik Indonesia Nonor 43 Tahun 2014 menyebutkan dalam Pasal 110 ayat (2) bahwa Pengelolaan kekayaan milik Desa diatur dengan peraturan Desa yang berpedoman pada Peraturan Menteri. Begitu pula Peratura Menteri Dalam Negeri Nomor 1 Tahun 2016 dalam Pasal 11 ayat (3) menyatakan jika dalam memanfaatkan aset Desa, pemerintah Desa harus menetapkan dalam Peraturan Desa.

Pemerintah desa disini melakukan perjanjian dengan pihak lain untuk memanfaatkan aset desanya, maka perjanjian yang dibuat dengan pihak lain dengan tidak adanya peraturan desa sebagai acuan perjanjian yang dilakukan dapat batal demi hukum.

\section{Kesimpulan}

Berdasarkan pembahasan di atas, maka dapat ditarik kesimpulan sebagai berikut :

1. Dari data yang dihimpun penulis, di kedua desa yakni Desa Getas Pejaten dan Ngembal kulon salah satu desa yakni Desa Ngembal Kulon belum melakukan mekanisme pemanfaatan aset desa sesuai peraturan Perundangundangan berlaku. Hal ini dibuktikan dengan mereka tidak 
mempunyai peraturan desa yang mengatur tentang pemanfaatan aset desa. Karena mereka tidak melaksanakan mekanisme dengan benar, maka mereka tidak mendapatkan hasil yang diharapkan yaitu meningkatkan pendapatan desa, hal ini dibuktikan dengan hasil wawancara penulis dengan kepala desa ngembal kulon yang menatakan bahwa mereka merugi karena sewa yang di hutang selama 3 tahun. Menurt UU Desa, pemanfaatan aset Desa haruslah dilakukan dengan berdasarkan asas kepentingan umum, fungsional, kepastian hukum, keterbukaan, efisiensi, efektivitas, akuntabilitas, dan kepastian nilai ekonomi. Para kepala desa belum memanfaatkan aset desa dengan asas keterbukaan, belum melakukan keterbukaan dengan para warga masyarakat sekitar. Hal ini dibuktikan dengan kesulitan penulis mencari data tentang aset desa di Desa Ngembal Kulon.

2. Pemanfaatan Aset Desa haruslah berdasarkan pada perundangundangan yang berlaku, salah satu syaratnya yaitu dengan memiliki perdes terlebih dahulu sebelum memanfaatkan aset desanya. Setiap tindakan hukum pemerintah harus didasarkan pada peraturan perundang-undangan yang berlaku, jika tindakan hukum pemerintah tidak sesuai dengan perundangundangan yang berlaku maka dapat menyebabkan akibat hukum yaitu batal demi hukum atau dapat dibatalkan. Pemerintah Desa dalam melakukan pemanfaatan harus berpedoman pada perdes, jika tidak memiliki peraturan Desa, maka perjanjian yang dibuat oleh pemerintah desa dapat batal demi hukum. Dikarenakan tidak memenuhi syarat obyektif yaitu kausa yang halal. Karena pada dasarnya pemerintah desa dalam melakukan perjanjian tunduk pada hukum privat.

\section{Saran}

Saran Untuk Pemerintah Desa :

1. Pemerintah Desa haruslah membuat sertifikat hak milik bagi aset-aset desanya.

2. Sebelum melakukan pemanfaatan, haruslah dilihat terlebih dahulu apakah nanti akan membuat desa semakin maju atau justru malah mengalami kerugian.

3. Pemerintah desa harus terbuka dalam memanfaatkan aset desa yang dimiliki.

Saran Untuk Pemerintah Kabupaten Kudus :

1. Melakukan pembinaan kepada desa-desa terlebih dalam hal pembuatan peraturan desa.

2. Membuat perda tentang pemanfaatan aset desa

Saran Untuk Pihak Penyewa :

1. Sebelum melakukan perjanjian, lihatlah terlebih dahulu hak dan kewajiban.

2. Sebelum melakukan perjanjian haruslah dilihat terlebih dahulu kepemilikan sah tanah yang akan dijadikan obyek perjanjian.

\section{DAFTAR PUSTAKA}

Amin Suprihatini, Pemerintahan Desa dan Kelurahan, Cempaka Putih, Jakarta, 2009.

Angger Wijaya, Reformasi Tata Pemerintahan Desa Menuju 
Demokratis, Pustaka Pelajar, Yogyakarta, 2000.

Bintoro Tjokroamidjojo, Good Governance (Paradigma Baru Manajemen Pembangunan),

Rineka Cipta, Jakarta, 2000.

HAW. Widjaja, Otonomi Desa, Rajawali Pers, Jakarta, 2004.

Ridwan, HR, Hukum Administrasi Negara, UII Press Yogyakarta, Yogyakarta, 2003.

Ronny Hanitijo Soemitro, "Metode Penelitian Hukum dan Jurimetri", Ghalia Indonesia, Jakarta, 1983.

\section{Peraturan Perundang-Undangan}

UUD NRI Tahun 1945

UU No. 6 Tahun 2014 tentang Desa
PP No. 43 Tahun 2014 tentang Peraturan Pelaksanaan UU No. 6 Tahun 2014 tentang Desa

PP No. 47 Tahun 2015 tentang Perubahan Atas PP No. 43 Tahun 2014 tentang Desa

Permendagri No. 1 Tahun 2016 tentang Pengelolaan Aset Desa

Peraturan Daerah Kabupaten Kudus Nomor 17 Tahun 2006 tentang Keuangan Desa

Peraturan Daerah Kabupaten Kudus Nomor 9 Tahun 2008 tentang Perubahan Atas Peraturan Daerah Kabupaten Kudus No. 17 Tahun 2006 tentang Keuangan Desa Peraturan Bupati Kudus No. 16 Tahun 2015 tentang Pedoman Pengelolaan Keuangan Desa 